\title{
Pressure Drop through Metallic Foam
}

\author{
Ahmed Kouidri* \\ University of Science and Technologie Houari Boumediene, Algeria
}

Submission: July 05, 2017; Published: August 22, 2017

*Corresponding author: Ahmed Kouidri, Laboratory of Multiphase Transport and Porous Media (LTPMP), Faculty of Mechanical and Process Engineering (FGMGP)/USTHB, BP. 32, El Alia, Algiers, Algeria, Tel: + 213-0-21-20-77-64; Email: akouidri@usthb.dz/ hmed_gc@hotmail.com

\section{Mini Review}

The metallic foam presents a positive impact in fluid engineering; moreover, the latter can presents also a significant pressure drop which was the aim of several studies.

Boomsma et al. [1] studied experimentally the influence of compressibility and pore scale, they found that the increasing in compressibility factor decrease the permeability, and the latter will be more sensible in front of permeability. Dukhan et al. [2] demonstrated that the pressure drop, in quadratic form, increase with increasing in pore density (PPI). They make also a new correlation that link the permeability with the inertial coefficient. We note that Guarino et al. [3] reported the same remark. The experiences of Manchin et al. [4] demonstrated that the pressure drop increase with decreasing in relative density (defined as the metallic foam density per material density).

Concerning the metal foam made from copper, the work of Xianbing et al. [5] and Gerbaux et al. [6] depict the pore density influence on the friction factor, where, the latter increase fastly in low pore density values, for constant porosity.

In the standard literature, the pressure drop is measured, generally, between the inlet and outlet of channels, using two pressure sensors. But Madani et al. [7,8] are measured the static pressure along the channel, using several pressure sensors. This method permits the elimination of inlet and outlet effects. Zhao et al. [9] compared the pressure drop of two types of materials: copper and FeCrAlY. They reported that the latter is more important in the case of copper metallic foam compared to the FeCrAlY, for the same pore density and relative density. The results of Hamadouche et al. [10] demonstrate that the insertion of aluminum metallic foam, in turbulent flow, can enhance the heat transfer coefficient with factor of $300 \%$ compared to the smooth channel. Kouidri et al. [11] characterized three metallic foam, Copper, NiFeAlCr and Inconel, with different surface roughness, their results show that the pressure drop increase from the smooth metallic foam to the rough one, they report also that the permeability changes from type of flow to another for each metallic foam samples. The theoretical studies in these fields are rare; Fourie et al. [12] established a theoretical model based on the morphological proprieties and the hydraulic diameter of elementary representative cell. This model gives a best precision in the prediction of pressure drop during Darcy and Forchheimer regimes. Boomsma et al. [13] developed a new approach for the modelization of fluid flow through metallic foam. It emulates a periodic boundary conditions -inlet-outlet-, makes the fluid flow with a specified volumetric flow rate and adjusted inlet velocity distribution to the outlet one. The results are very close to those of experiments.

For adiabatic two phase flow, Topin et al. [14] analyzed an adiabatic two phase (air-water) flow through metallic foam samples, made from Copper and Nickel, with different pore density. This study was based on two phase multiplier. Calvo et al. [15] used the micro-tomography rayon $X$ and radiography rayon $\mathrm{X}$ to characterize the hydrodynamic proprieties of liquidgas flow, in counter-current, through metallic foam. The dynamic and static distributions of liquid quality were measured. The present literature analysis shows that, there is a significant dispersion in results; this is due, certainly, to the non-uniformed method of measure and several morphologic properties of metallic foam, which is ignored by the authors.

\section{References}

1. Boomsma K, Poulikakos D (2002) The effects of compression and pore size variations on the liquid flow characteristics in metal foams. Journal of fluids engineering 124(1): 263-272.

2. Dukhan N (2006) Correlations for the pressure drop for flow through metal foam. Experiments in fluids 41(4): 665-672.

3. Guarino S, Rubino G, Tagliaferri V, Ucciardello N (2015) Thermal behavior of open cell aluminum foams in forced air: Experimental analysis. Measurement 60: 97-103.

4. Mancin S, Zilio C, Cavallini A, Rossetto L (2010) Pressure drop during air flow in aluminum foams. International Journal of Heat and Mass Transfer 53(15): 3121-3130.

5. Ji X, Xu J (2012) Experimental study on the two-phase pressure drop in copper foams. Heat and Mass Transfer 48(1): 153-164. 


\section{Civil Engineering Research Journal}

6. Gerbaux O, Vercueil T, Memponteil A, Bador B (2009) Experimental characterization of single and two-phase flow through nickel foams. Chemical Engineering Science 64(19): 4186-4195.

7. Madani B, Topin F, Rigollet F, Tadrist L (2007) Flow laws in metallic foams: experimental determination of inertial and viscous contributions. Journal of porous media 10: 51-70.

8. Madani B, Topin F, Tadrist L (2010) Convective boiling in metallic foam: experimental analysis of the pressure loss. Fluid Dynamics \& Materials Processing 6(4): 351-367.

9. Zhao C, Kim T, Lu T, Hodson H (2001) Thermal transport phenomena in porvair metal foams and sintered beds. Final Report, University of Cambridge, USA.

10. Hamadouche A, Nebbali R, Benahmed H, Kouidri A, Bousri A (2016) Experimental investigation of convective heat transfer in an open-cell aluminum foams. Experimental Thermal and Fluid Science 71: 86-94
11. Kouidri A, Madani B (2016) Experimental hydrodynamic study of flow through metallic foams: Flow regime transitions and surface roughness influence. Mechanics of materials 99: 79-87.

12. Fourie JG, Du Plessis JP (2002) Pressure drop modeling in cellular metallic foams. Chemical Engineering Science 57(14): 2781-2789.

13. Boomsma K, Poulikakos D, Ventikos Y (2003) Simulations of flow through open cell metal foams using an idealized periodic cell structure. International Journal of Heat and Fluid Flow 36: 825-834.

14. Topin F, Bonnet JP, Madani B, Tadrist L (2006) Experimental analysis of multiphase flow in metallic foam: flow laws, heat transfer and convective boiling. Advanced Engineering Materials 8(9): 890-899.

15. Calvo S, Beugre D, Crine M, Léonard A, Marchot P, et al. (2009) Phase distribution measurements in metallic foam packing using X-ray radiography and micro-tomography. Chemical Engineering and Processing: Process Intensification 48(5): 1030-1039.

\section{Your next submission with Juniper Publishers will reach you the below assets}

- Quality Editorial service

- Swift Peer Review

- Reprints availability

- E-prints Service

- Manuscript Podcast for convenient understanding

- Global attainment for your research

- Manuscript accessibility in different formats

( Pdf, E-pub, Full Text, Audio)

- Unceasing customer service

Track the below URL for one-step submission https://juniperpublishers.com/online-submission.php 